\title{
The Study of the Level of Knowledge, Attitude, Practices (KAP) as well as the Effects of School Environment on the Nutritional Status of Children (7-12) Coming from Affluent Families in the Dhaka City in Bangladesh
}

\author{
Sanjoy Saha $^{1}$, Md.Khurshidul Zahid ${ }^{1 *}$, Sabrina Rasheed ${ }^{2}$ \\ Institute of Nutrition and Food Science, University of Dhaka ${ }^{1}$ \\ Social and Behavioural Sciences Unit, ICDDR,B, Dhaka-1000 ${ }^{2}$
}

\begin{abstract}
:
The study find-out the level of knowledge, attitude and practices and effects of school environment on the nutritional status of children(7-12 yrs) coming from affluent society in Dhaka city in Bangladesh. Majority(68.31\%) of the students have basic Nutritional Knowledge but only $70.20 \%$ students have correct basic Nutritional Knowledge. Each school gives basic nutrition education to their students along with the general courses, so that the students as well as their parents adopt healthy eating practices. All schools have classroom teaching programme related to Food and Nutrition. On average students spend 4.8 hours per day at school. Though all schools have indoor sports facilities but students are mostly involved in sedentary activities. Majority (86.5\%) of the students participates in indoor sports \& extracurricular activities at school as well as almost half (47.91\%) of the students take part in outdoor sports. One fifth (18.75\%) of students spend more than one hour in extracurricular activities. From this study it is found that there is a significant negative relationship between duration of physical activity (sports and extracurricular activities) at school and over-nutrition (obesity \& overweight). In case of students' parents, most $(59.37 \%)$ of the fathers are businessman and most (67.7\%) of the mothers are housewife. About $59 \%$ of students get their pocket money from their mother. About two-third (65.6\%) of students take foods from the shops for their school meal and only one third (34.4\%) of the students bring foods from home for their school meals. Students spend on an average 24 taka at school to buy foods. Each school have indoor food facilities. Most foods available in the shops inside the schools are fast foods which are mainly rich in calories. Most (72.9\%) students consume fast foods and fried foods in school hours. They mostly prefer fast foods and soft drinks who buy foods at school. Intake of fruits, milk and milk product is low. If he or she get extra pocket
\end{abstract}

Bangladesh Journal of Nutrition. Vol. 24-25 December, 2011-2012. Institute of Nutrition and Food Science, University of Dhaka, Dhaka-1000, Bangladesh.

* Author for Correspondence 
money then they prefers to buy firstly ice-cream and then chocolate, soft drinks and fruit juices which are mainly energy rich foods. Most (78.1\%) students consume fast foods while they are at school but while they are away from school they preferred to take dairy products (96.7\%) as well as fruits and vegetables (93.7\%). Most of the students (92.70\%) take fast foods 1-3 times per week while three fourth of the students (75\%) students drink soft drinks 1-3 times per week. Majority of students prefer to have fast foods (68.75\%) and soft drinks (58.33\%) at afternoon. There is no significant relationship between fast food intake at school and overweight development. High percentage of overweight among the studied subjects possibly due to total intake both at home and outside. From the study we can say that if both the students and parents are given sufficient nutritional knowledge then there is a fair chance to develop a healthy environment in each school which will lead them to choose and eat healthy foods to make their diet balanced. We need immediate measures to control malnutrition problems of children coming from affluent societies in Dhaka city. If proper steps are taken quickly then we can hope a healthy nation with healthy children.

Key words: School environments, Nutritional status, Overweight and Obesity.

\section{Introduction:}

Childhood overweight and obesity is a condition where excess body fat negatively affects a child's health or wellbeing. All children and adolescents reach schools during their first two decades in life. For this reason schools are ideal settings for influencing nutritional status of children. School environment can have a significant impact on children food choice. Now a days, schools of affluent societies generally provide mostly fast foods and beverages which are dense in calories. Children who eat fast food, compared with those who do not, consume more total energy (calories), more energy per gram of food, more total fat, more total carbohydrate, more added sugar, more sugar sweetened beverages, less fiber, more milk and few fruits and non starchy vegetable, are vulnerable to develop obesity problem. To understand the prevalence of overweight and obesity among children and youth, it is important to examine the role of different factors in the school environment.

In developed countries, school environment is recognized as having a powerful influence on students eating behaviors' (15). School age is a prime time for learning about healthy lifestyles and incorporating them in to daily behaviors. School can provide an environment for nutrition education and learning healthy lifestyle (8). Children between the ages of five and 13 spend an average of 6.5 hours a day at school and almost all elementary school children eat at least one meal a day in the school (12). In today's schools students are offered a variety of eating options and opportunities, they purchase single food items from snack bars, vending machine, canteen and school stores and in some cases they are allowed to leave school to buy food (15). An Obesogenic school promotes positive energy balance. This occurs 
when the average energy intake of students from food and beverages consumed in the school setting is high and the energy expended in school through playground activity, physical education classes and incidental activity is low (16). The growing stream of commercial messages, food advertisements and easy access to high fat and high sugar food products as well as a large of portion sizes and lower prices. In school are at cross purposes and direct conflict with the goal of nutrition education, and may negate the efforts in the classroom and lunchroom to foster eating practices (8).

Excessive sweetened drink consumption is associated with greater weight gain and the odds of becoming obese may increase by as much as $60 \%$ with each additional serving of sugar-sweetened drinks that a child consumes. One serving $(250 \mathrm{ml})$ of a soft drink is broadly equal to $130 \mathrm{kcal}$ (17). Vending machine or school stores can be found in $43 \%$ of elementary, $74 \%$ of middle junior high and $98 \%$ of high school corridors. $69 \%$ of schools allow students to purchase foods and beverages from these sources during school lunch periods. Most of foods in school vending machines and school stores are high fat or high sugar items such as snack chips, candy and soft drinks (8). According the NHANES iii data, children aged 6 to 11 years obtain about $20 \%$ of their total energy intake from beverages, with milk, soft drinks, snacks, and food juice being the largest contributors (8). In a typical surveyed high school of 1000- plus students, and despite the universal availability of fresh fruit in these school cafeterias, as little as 3-5 pieces of fruit in total per day were purchased. It is clear that when other poor nutrition snack and dessert products are available, the vast majority of students opted for them instead of fruit (18).

The rising prevalence of obesity in children may be due to a reduction in physical activity (PA) (17). School age youth should participate daily in 60 minutes or more of moderate to vigorous physical activity that is developmentally appropriate, enjoyable and involves a variety of activities (19). Schools have been recognized as key setting both to promote and to contribute to physical activity because children spend such a large proportion of their time there. In a study result, most schools lack spacious school yards and are defined as mostly crowded and congested during recess. Students have limited outdoor space for both play and physical activity (20). Nutritional authorities have argued that the schools can play a key role in reversing the trend towards childhood obesity (21).

Under nutrition is one of the most important problems in developing countries. Now a day's prevalence of over-nutrition (overweight and obesity) in children coming from affluent societies of developing countries is increasing rapidly. So, it is a double burden of nutritional problems among children in the developing countries like Bangladesh. The magnitude of overweight and obesity is a global public health problem (WHO, 2005); as there has been an upward trend in the prevalence of obesity both in developed and developing countries. Bangladesh, a country with a large economic burden due to under nutrition, now has to deal with 
over nutrition as well. Excess body weight is a result of an imbalance between energy intake and energy expenditure (4). Childhood obesity has emerged as a critical health problem of the $21^{\text {st }}$ century. The most prevalent immediate consequence for obese children is social isolation and peer problem. The most important consequence of childhood overweight and obesity is a greater risk of obesity in adulthood (7). Previous research had identified several possible causes of overweight and obesity these include the high prevalence including intrauterine, malnutrition, eating behavior and lifestyle practice, especially in urban areas (11). Several reports have shown that the Bangladesh has limited dietary diversity and poor eating behavior, while that is in part due to poverty, it also been found that fats and oils constitute a large proportion of the daily diet of people with higher socioeconomic status and that most of the population does not consume adequate fruits and vegetables (11). Societal changes and worldwide nutrition transition are driving the obesity epidemic (3). In the last few decades, children have become less active as a result of their easy access to technological advances such as video games, television (7). Bangladesh faces a double burden of both of malnutrition with chronic energy malnutrition (CED) remaining the dominant nutritional phenotype (11). Over weight is more prevalent in relatively higher socio-economic groups (11).

In Bangladesh, overweight and obesity are growing trends in the adult. It is important therefore, to assess the situation of the school age children. Children's spent 5-6 hours daily at school and therefore, school environment can influence the food intake of the children. If school environment is obsesogenic it can contribute to the prevalence of childhood overweight and obesity. We have selected affluent schools for our study as these schools have the resources to address the problems that are identified through the study.

\section{Materials and Methods:}

This research had been conducted in Dhaka city at three English medium schools among children of 7 to 12 years which are mainly from Grade I, II and III. These schools were representative of the affluent society. Schools were selected based on the following criteria: tuition fees, location, availability of cafeteria, vending machines, and fast food shops in or near the school.

\section{Study Design: Cross-sectional.}

\section{Development of Questionnaire:}

A standard questionnaire was developed for collecting data on socioeconomic, dietary and KAP (Knowledge, attitude and practices) information. The questionnaire was pre-tested and modified on the basis of test results for the present study. 


\section{Collection of data:}

After attaining consents from school authority and parents, data were collected from three schools on three different days. Tosurtal number of students participated in the survey was 96 (Male-70, Female-26).

\section{Dietary assessment:}

Dietary data was collected by a standardized questionnaire which was developed by different methods such as 24 hour-recall method, dietary history and food frequency questionnaire.

\section{Physical activity level:}

Daily educational and extracurricular activity levels were determined by structured interview of all study participants.

\section{Socio-economic questionnaire:}

Socio-economic status (SES) data of the children's and their families were collected by using standardized questionnaire.

\section{Data analysis:}

This proposed research had both quantative and qualative components. Data was analyzed by SPSS-12 software. SPSS-12 software was used to organize, analyze and statistical analysis of the quantative and qualative data.

\section{Results:}

Socio-economic data:

Total students-96 (Male $=70$, Female=26)

Age $=86-143$ months (7-12 years)

Total schools surveyed $=3$

Table-1: Duration of school hours in the schools surveyed.

\begin{tabular}{|c|c|c|}
\hline \multicolumn{3}{|c|}{ Total time of School/ Day } \\
(Hours)
\end{tabular}

Table- 1 shows that students spend $4.80 \pm 0.55$ hours per day at school. 
Graph-1: Proportion of students of different grades involved in the study.

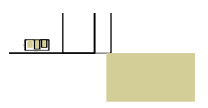

Table-2: Sources of pocket money to buy foods at school.

\begin{tabular}{|c|c|}
\hline Source's of Pocket Money & Students \% \\
\hline Father & 11.11 \\
\hline Mother & 58.73 \\
\hline Both & 38.16 \\
\hline
\end{tabular}

Table -2 shows that most (58.78\%) students get their pocket money from their mother.

Table-3: Parents’ Occupation category.

\begin{tabular}{|c|c|c|}
\hline Occupation & Father (\%) & Mother (\%) \\
\hline Business & 59.37 & 7.29 \\
\hline Teacher & 4.16 & 7.29 \\
\hline Doctor & 2.08 & 1.04 \\
\hline Arm force & 6.25 & 0 \\
\hline House hold & 0 & 67.70 \\
\hline Other Services & 28.12 & 16.67 \\
\hline
\end{tabular}

Table-3 shows that most of the fathers are businessman $(59.37 \%)$ and most of the mothers are housewife (67.7\%). 
Graph-2: Father's occupation.

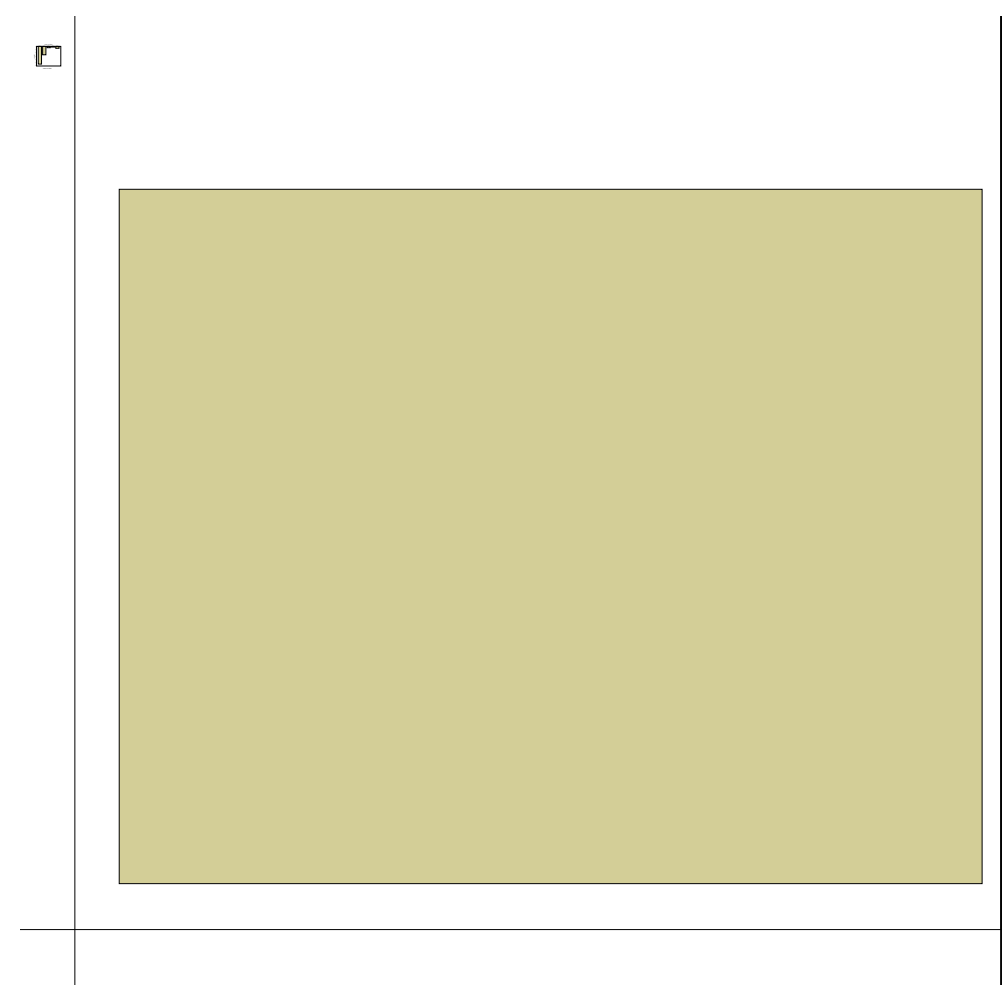

Graph-3: Mother's occupation

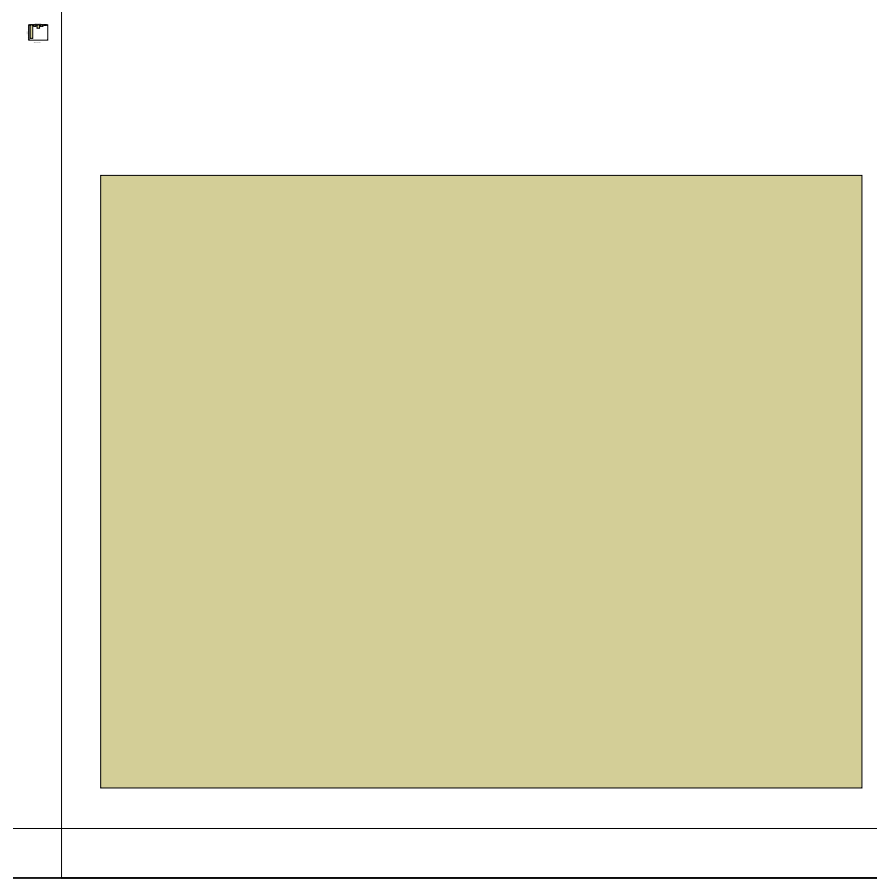


Table-4: Involvement in extracurricular activities.

\begin{tabular}{|l|c|c|c|c|}
\hline \multirow{2}{*}{\multicolumn{1}{|c|}{ Types of activity }} & Students & \multicolumn{3}{|c|}{ Time(Min) } \\
\cline { 3 - 5 } & \%inimum & Maximum & Mean \pm SD \\
\hline $\begin{array}{l}\text { Indoor sports \& } \\
\text { extracurricular activities }\end{array}$ & 86.5 & 15 & 45 & $18 \pm 12.15$ \\
\hline Outdoor sports & 47.91 & 10 & 60 & $26.95 \pm 15.10$ \\
\hline
\end{tabular}

Table -4 shows that majority (86.5\%) of the students participate indoor sports \& extracurricular activities at school as well as almost half $(47.91 \%)$ of the students take part in outdoor sports . One fifth $(18.75 \%)$ of students spend more than 1 hours in extracurricular activities.

Table-5: Relation between Time Spend for sports and Extracurricular activities and obesity development in children assessed.

\begin{tabular}{|c|c|c|c|}
\hline $\begin{array}{c}\text { Time Spend for sports } \\
\text { and Extracurricular } \\
\text { activities } \\
\text { (Min) }\end{array}$ & \multicolumn{2}{|c|}{$\begin{array}{c}\text { Participation by different } \\
\text { groups }\end{array}$} & $\begin{array}{c}\text { Chi-Square test } \\
\text { P-value } \\
\text { (2-Sided) }\end{array}$ \\
\cline { 2 - 3 } & Obese & Non-obese & \\
\hline 0 & 4.4 & 9.8 & \multirow{2}{*}{0} \\
\hline 15 & 73.3 & 2.0 & \multirow{2}{*}{0.00} \\
\hline 30 & 11.1 & 9.8 & \\
\hline 45 & 11.1 & 74.5 & \\
\hline
\end{tabular}

Table- 5 shows that there is a significant negative relationship between time spend for sports and extracurricular activities and obesity development.

Dietary data:

Table-6: Sources of foods taken at school.

\begin{tabular}{|c|c|}
\hline Sources & Students (\%) \\
\hline Generally buy foods from shops at school & 65.6 \\
\hline Generally bring foods at school from home & 34.4 \\
\hline
\end{tabular}

Table-6 shows about two-third (65.6\%) of students take foods from the shops inside the school and only one third (34.4\%) of the students bring foods from home for their school meals. 
Table -7: Expenditure on foods (Tk).

\begin{tabular}{|c|c|c|}
\hline Minimum & Maximum & Mean \pm SD \\
\hline 15 & 50 & $23.97 \pm 9.42$ \\
\hline
\end{tabular}

Table-7 shows that students spend on an average 24 taka at school to buy foods.

\section{Graph-4: Foods preference at school.}

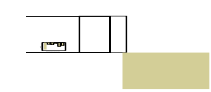

Graph-4 shows that students mostly prefers fast foods and soft drinks who buy foods at school

Graph-5: Students want to buy, after getting some money.

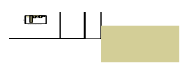

Graph-5 shows that students prefer to buy mostly ice-cream and then chocolate, soft drinks and fruit juices which are mainly energy rich foods with his/her extra pocket money. 
Bangladesh J. Nutr. Vol. 24-25 Dec 2011-2012

Table-8: Eating habits of junk foods.

\begin{tabular}{|c|c|c|}
\hline \multirow{2}{*}{$\begin{array}{c}\text { Frequency of intake per } \\
\text { Week }\end{array}$} & \multicolumn{2}{|c|}{ Students (\%) } \\
\cline { 2 - 3 } & Fast foods & Soft drinks \\
\hline Never & 0 & 0 \\
\hline $1-3$ times & 92.70 & 21.87 \\
\hline 4-6 times & 5.20 & 3.12 \\
\hline$\geq 7$ times & 2.08 & Soft drinks \\
\hline Time of intake per Week & Fast foods & 26.04 \\
\hline Morning & 0 & 58.33 \\
\hline Afternoon & 68.75 & 0 \\
\hline Noon & 18.75 & 0 \\
\hline Afternoon & 11.45 & 15.62 \\
\hline Night & 0 & \\
\hline
\end{tabular}

Table-8 most of the students $(92.70 \%)$ take fast foods 1-3 times per week while three fourth of the students(75\%) students drink soft drinks 1-3 times per week. Majority of students (68.75\%) prefer to have fast foods at afternoon. The rest preferred fast foods at noon and night. Major portion of the students (58.33\%) like to soft drinks at afternoon. The rest preferred to drink in morning and night.

Table-9: Foods available at shops in different school.

\begin{tabular}{|c|c|}
\hline Food Items & Schools (\%) \\
\hline Burger and Sandwitch & 100 \\
\hline Pizza ,Chicken roll ,Shamucha and Shingara & \multirow{4}{*}{66.67} \\
\hline Chips, Biscuits & \\
\hline Dairy chocolate & \\
\hline Soft drinks and Fruit drinks & \\
\hline $\begin{array}{l}\text { Potato chop , Patties, Cup cake, Vegetables roll, } \\
\text { Hot dog and Club sandwich }\end{array}$ & 33.33 \\
\hline
\end{tabular}

Table-9 shows most foods available in the shops inside the schools are fast foods which are mainly rich in calories. Fast foods are a type of food that is quickly made, but of low nutritional value; junk food 
Rahman and Islam : Nutritional Status and Food Security

Table-10: Foods of different groups taken by the students at school meals (24Recall method).

\begin{tabular}{|l|c|}
\hline \multicolumn{1}{|c|}{ Food Items } & $\begin{array}{c}\text { Student Taken } \\
\text { Foods } \\
\text { (\%) }\end{array}$ \\
\hline Fast foods and Fried foods & 72.9 \\
\hline Soft drinks & 7.3 \\
\hline High sugar containing foods & 4.2 \\
\hline & \multicolumn{2}{|c|}{} \\
\hline Rice, Bread & 20.8 \\
\hline Meat (Beef , Mutton) & 0.0 \\
\hline Fish, Egg and Poultry & 10.4 \\
\hline Milk and Milk products & 2.1 \\
\hline Fruits & 5.2 \\
\hline Green leafy vegetables & 0.0 \\
\hline Vegetables & 0.0 \\
\hline
\end{tabular}

Table-10 shows that most (72.9\%) students consume fast foods and fried foods in school hours. Intake of fruits, milk and milk product is low whereas intake of vegetable is nil. 
Bangladesh J. Nutr. Vol. 24-25 Dec 2011-2012

Table-11: Foods of different groups taken at hours spend outside the school (24-Recall method).

\begin{tabular}{|c|c|c|c|c|c|}
\hline \multirow{3}{*}{ Food items } & \multicolumn{5}{|c|}{ Time of Meal } \\
\hline & Breakfast & Lunch & Afternoon snacks & Dinner & Before sleep \\
\hline & \multicolumn{5}{|c|}{ Students Taken Foods (\%) } \\
\hline $\begin{array}{l}\text { Milk and } \\
\text { Milk } \\
\text { products }\end{array}$ & 35.4 & 0.0 & 6.3 & 1.0 & 27.1 \\
\hline $\begin{array}{l}\text { Rice and } \\
\text { Breads }\end{array}$ & 93.8 & 98.9 & 61.4 & 94.8 & 3.1 \\
\hline $\begin{array}{l}\text { Meat (Beef, } \\
\text { Mutton) }\end{array}$ & 2.1 & 12.5 & 0.0 & 16.7 & 0.0 \\
\hline $\begin{array}{l}\text { Fish, Egg } \\
\text { and Poultry }\end{array}$ & 46.8 & 90.6 & 12.5 & 85.4 & 0.0 \\
\hline $\begin{array}{l}\text { Green leafy } \\
\text { vegetables }\end{array}$ & 1.0 & 24.0 & 0.0 & 6.3 & 0.0 \\
\hline Vegetables & 5.2 & 34.4 & 0.0 & 31.3 & 0.0 \\
\hline Fruits & 8.3 & 2.1 & 15.6 & 1.0 & 19.8 \\
\hline Soft drinks & 0.0 & 9.4 & 20.8 & 1.0 & 0.0 \\
\hline $\begin{array}{l}\text { Fast foods } \\
\text { and Fried } \\
\text { foods }\end{array}$ & 5.2 & 1.0 & 20.8 & 0.0 & 0.0 \\
\hline $\begin{array}{l}\text { High sugar } \\
\text { containing } \\
\text { foods }\end{array}$ & 16.7 & 1.0 & 7.3 & 1.0 & 0.0 \\
\hline
\end{tabular}


Table-12: Comparison of students eating practices at school and outdoor.

\begin{tabular}{|c|c|c|}
\hline \multirow[t]{2}{*}{ Types of food items } & \multicolumn{2}{|c|}{$\begin{array}{c}\text { Students } \\
\%\end{array}$} \\
\hline & At school & Outdoor \\
\hline Fast foods and fried foods & 78.1 & 21.9 \\
\hline High sugar containing foods & 12.5 & 87.5 \\
\hline Dairy foods & 3.1 & 96.9 \\
\hline Fruits and Vegetables & 6.3 & 93.7 \\
\hline
\end{tabular}

Table-12 shows that most (78.1\%) students consume fast foods while they are at school but while they are away from school they preferred to take dairy products(96.7\%) as well as fruits and vegetables(93.7\%).

Table-13: Facilities of Food service and Nutrition education in different schools surveyed.

\begin{tabular}{|c|c|}
\hline Services & $\begin{array}{c}\text { Schools } \\
\text { \% }\end{array}$ \\
\hline Availability of indoor food services in school & 100 \\
\hline Schools operate food services for profit or fund raising & 100 \\
\hline $\begin{array}{c}\text { Classroom teaching programme related to Food and } \\
\text { Nutrition }\end{array}$ & 100 \\
\hline $\begin{array}{c}\text { Teachers encourage children to adopt healthy eating } \\
\text { behaviors }\end{array}$ & 66.67 \\
\hline $\begin{array}{c}\text { Teachers provide information to parents about healthy } \\
\text { food }\end{array}$ & \\
\hline
\end{tabular}


Table- 14: Relation between types food intake and obesity development in children assessed.

\begin{tabular}{|l|c|c|c|}
\hline \multirow{2}{*}{$\begin{array}{l}\text { Types of foods and Places of } \\
\text { intake }\end{array}$} & \multicolumn{3}{|c|}{$\begin{array}{c}\text { Intake of foods by different group of } \\
\text { students } \\
\text { \% }\end{array}$} \\
\cline { 2 - 4 } & Obese & Non-obese & $\begin{array}{c}\text { Chi-Square test } \\
\text { P-value } \\
\text { (1-sided) }\end{array}$ \\
\hline Fast food at school & 75.6 & 80.4 & 0.372 \\
\hline Fast food at outdoor & 31.1 & 37.3 & 0.339 \\
\hline $\begin{array}{l}\text { High sugar containing foods at } \\
\text { school }\end{array}$ & 13.3 & 11.8 & 0.529 \\
\hline $\begin{array}{l}\text { High sugar containing foods at } \\
\text { outdoor }\end{array}$ & 53.3 & 43.1 & 0.214 \\
\hline Dairy foods at school & 2.2 & 3.9 & 0.547 \\
\hline Dairy foods at outdoor & 55.6 & 52.9 & 0.480 \\
\hline Fruits and Vegetables at school & 4.4 & 7.8 & 0.400 \\
\hline $\begin{array}{l}\text { Fruits and Vegetables at } \\
\text { outdoor }\end{array}$ & 80.0 & 90.2 & 0.131 \\
\hline
\end{tabular}

Table-14 shows that there is no significant relation between types of food and obesity development.

Data on Knowledge, Attitude and Practices:

Table-15 : Findings of basic Nutritional Knowledge of students.

\begin{tabular}{|c|c|}
\hline Nutritional Knowledge & Students \% \\
\hline Junk foods help to develop obesity. & 44.79 \\
\hline Fruits and vegetables help to maintain good health. & 70.83 \\
\hline Justified their weight as right. & 60.40 \\
\hline Fruits is a healthy food. & 81.25 \\
\hline Prefer to have fast foods in the school premises. & 58.83 \\
\hline Believe that physical exercise is good for health. & 93.75 \\
\hline Basic Nutritional Knowledge of students & $\mathbf{6 8 . 3 1}$ (Average) \\
\hline
\end{tabular}


Table 16: Justification of basic Nutritional knowledge of the students.

\begin{tabular}{|l|c|c|c|}
\hline \multirow{2}{*}{} & \multicolumn{2}{|c|}{ Level of Knowledge of Students assessed } \\
\cline { 2 - 4 } & Correct & $\begin{array}{c}\text { Partially } \\
\text { correct }\end{array}$ & Incorrect \\
\hline Food that leads to overweight & 44.79 & 36.45 & 18.75 \\
\hline $\begin{array}{l}\text { Foods that contribute to good } \\
\text { heath }\end{array}$ & 70.83 & 14.58 & 15.62 \\
\hline $\begin{array}{l}\text { Perception about own body } \\
\text { weight }\end{array}$ & 60.40 & 0 & 39.60 \\
\hline $\begin{array}{l}\text { Understanding about "good” } \\
\text { foods }\end{array}$ & 81.25 & 9.37 & 9.37 \\
\hline Benefit of exercise & 93.75 & $\mathbf{1 2 . 0 8}$ & $\mathbf{1 7 . 9 2}$ \\
\hline Basic Nutritional Knowledge & $\mathbf{7 0 . 2 0}$ & \multicolumn{2}{|c|}{} \\
\hline
\end{tabular}

\section{Discussion:}

The present study included students of grade- 2, 3 and 4 .On average students spend 4.8 hours per day at school. So, it has a greater influence in their health status. About $59 \%$ of students get their pocket money from their mother. In case of students' parents, most of the fathers are businessman (59.37\%) and most of the mothers are housewife (67.7\%). So, in both cases mothers can play significant role in reducing over-nutrition problems as well as can be a major contributor in developing and maintaining proper health of children in affluent societies through investing their available time and channeling their money in proper ways. Majority (86.5\%) of the students participates indoor sports \& extracurricular activities at school as well as almost half (47.91\%) of the students take part in outdoor sports. One fifth (18.75\%) of students spend more than 1 hour in extracurricular activities. So, if we consider the time and type of activities to burn calories is very low. They mostly involved in sedentary activities. This may lead to overweight and obesity problems. From this study we found that there is a significant negative relationship between time spend for sports and extracurricular activities and obesity development. Each school have indoor food facilities. We found that about twothird (65.6\%) of students take foods from the shops for their school meal and only 
one third (34.4\%) of the students bring foods from home for their school meals. Most foods available in the shops inside the schools are fast foods which are mainly rich in calories. They mostly prefer fast foods and soft drinks who buy foods at school. Most (72.9\%) students consume fast foods and fried foods in school hours. Intake of fruits, milk and milk product is low. Students spend on an average 24 taka at school to buy foods. If he or she get extra pocket money then they prefers to buy firstly ice-cream and then chocolate, soft drinks and fruit juices which are mainly energy rich foods. Most of the students (92.70\%) take fast foods 1-3 times per week while three fourth of the students(75\%) students drink soft drinks 1-3 times per week. Majority of students prefer to have fast foods (68.75\%) and soft drinks (58.33\%) at afternoon. Most (78.1\%) students consume fast foods while they are at school but while they are away from school they preferred to take dairy products (96.7\%) as well as fruits and vegetables (93.7\%). This study showed that there is no significant relation between fast food intake at school and obesity development as we know that types of food as well as total amount of foods eaten may influence nutritional status of the children in a greater extend. $68.31 \%$ of the students have basic Nutritional Knowledge but $70.20 \%$ students have correct basic Nutritional Knowledge whereas $12.08 \%$ have partially correct and $17.92 \%$ students have incorrect knowledge. All schools have classroom teaching programme related to Food and Nutrition. At the same time school teachers encourage children to adopt healthy eating behaviors. Teachers also provide information to parents about healthy food. From the study we can say that if both the students and parents are given sufficient nutritional knowledge then there is a fair chance to develop a healthy environment in each school which will lead them to choose and eat healthy foods to make their diet balanced. We need immediate measures to control malnutrition problems of children coming from affluent societies in Dhaka city. If proper steps are taken quickly then we can hope a healthy nation with healthy children.

\section{References:}

1.Wen-Harn Pan, Katherine M Flegal , Hsing-Yichang, et al. Body mass index and obesity-related metabolic disorders in Taiwanese and US whites and blacks: implication for definitions of overweight and obesity for Asians. The American Journal of Clinical Nutrition 2004; 79:31-39.

2.Obesity,www.who.int/dietphysicalactivity/publications/facts/obesity/en.

3. Obesity and overweight, www.who.int/dietphysicalactivity/media/en/gsfs_obesity.pdf.

4.John M Jakicic, Amy D Otto. Physical activity considerations for the treatment and prevention of obesity. The American Journal of Clinical Nutrition 2005; 82(suppl):226S-226S. 
5. Centre for Control of Chronic Diseases in Bangladesh. ICDDR, B. Available at: www.icddrb.org/activity/index.jsp?activityObjectID=4386

6. Mejbah Uddin Bhuiyan. Risk Factors Associated With Overweight and Obesity among School Children in Dhaka City. Brac University. Available at: www.bracu.ac.bd/I\&S/sph/students/d.3rd.batch/Mejbah.Uddin.Bhuiyan.htm

7.H. Mozaflari, B.Nabaei. Obesity and related risk factors. Indian Journal of Pediatrics 2007; 74: 265-267.

8.Judith E. Brown,Janet Sugarman Isaacs, Maureen A.Murtaugh et al. $2^{\text {nd }}$ edition. Nutrition throughout life cycle. United States. Thomson Wadsworth; 2005:269-306.

9. Obese kids have arteries of 45-year-olds: study. CTV News. http://www.ctv.ca/servlet/ArticleNews/story/CTVNews/20081111/kids_arterie s_081111/20081111?hub=TopStories. Retrieved 2008-11-11.

10. Uptodate.com|http://www.uptodate.com/online/content/topic.do?topicKey=ped igast/13911\#25

11. Sohana Shafique, Nasima Akhter, Gudrun Stallkamp, Saskia de Pee, Dora Panagides. Trends of under- and overweight among rural and urban poor women indicate the double burden of malnutrion in Bangladesh. International Journal of Epidemiology.2007.

12. Elizabeth Hair, Thomson Ling, Laura Wander. School food unwrapped: What's available and what our kids actually are eating: A research brief. Child Trends 2008. Available at:www.healthinschools.org/ media/Files/obesityfs.ashx

13. Marie-Pierre St- Onge, Kathlean L Keller, Steven B Heymsfield. Changes in childhood food consumption patterns: a cause for concern in light of increasing body weights. Am J cling Nutr 2003; 78:1068-73.

14. Nicole L Nollen, Christie A Befort, Patricia Snow, et al. The school food environment and adolescent obesity: qualative insights from high school principles and food service personnel. International Journal of Behavioral Nutrition and Physical activity 2007; 4:18-22.

15. Martha Y. Kubik, Leslie A.Lytle, Peter J.Hannan, M.Statet et al .The association of the school food environment with dietary behaviors of young adolescents. American Journal of Public Health 2003; 93: 1168-1172.

16. AC Bell, BA Swinburn. What is the key food groups to target for preventing obesity and improving nutrition in schools? European Journal of Clinical Nutrition 2004; 58: 258-263. 
17. Ulf Ekelund, Luis B Sardinha, Sigmund A Anderssen, et al. Association between obesity assessed physical activity and indicators of body fatness in 9to 10-y-old European children:L a population-based study from 4 distinct regions in Europe (The European Youth Heart Study). Am J Cling Nutr 2004; 80:584-590.

18. Anthony Winson. School food environments and the Obesity issue:content, structural determents, and agency in condition high schools. Agric Hum Vaues 2008:25:499-511.

19. William B.Strong, MD’Robert M. Malina, Cameron J. R.Blumkie et al. Evidence based physical activity for school age youth. J Pediator 2005; 146:732-7.

20. Aydin Ozdemir, Oguz Yilmaz. Assessment of outdoor school environments and physical activity in Ankards Primary Schools. Journal of Environmental Psychology 2008; 28:287-300.

21. Briggs, M.S.Safaii, D.L.Beall. An essential component of comprehensive school health programs. Journal of American dietetic Association 2003; 103(4):505-514.

22. Nuhad Raisa Seoty. Prevalence of overweight among the adolescent school girls in Dhaka city. Institute of Nutrition and Food Science. M.Sc Thesis, 2004. 